KANTIAN REVIEW 


\title{
KANTIAN REVIEW
}

\author{
Editors \\ Howard Williams, Aberystwyth University \\ Graham Bird, University of Manchester \\ Richard Aquila, University of Tennessee
}

\author{
Editorial Board \\ Professor Henry Allison, University of California, Davis \\ Professor Marcia Baron, Indiana University \\ Professor Luigi Caranti, Università di Catania \\ Professor Katrin Flikschuh, London School of Economics and Political Science \\ Professor Michael Friedman, Stanford University \\ Professor Paul Guyer, Brown University \\ Professor Jürgen Habermas, University of Frankfurt \\ Professor Robert A. Hanna, University of Colorado \\ Professor Otfried Höffe, University of Tübingen \\ Professor Wolfgang Kersting, University of Kiel \\ Professor Jane Kneller, Colorado State University \\ Professor Alison Laywine, McGill University \\ Professor Ingeborg Maus, University of Frankfurt \\ Professor Adrian Moore, University of Oxford \\ Professor Onora O'Neill, University of Cambridge \\ Professor Gerold Prauss, Albert-Ludwigs-Universität Freiburg \\ Professor Hoke Robinson, University of Memphis \\ Professor Susan Shell, Boston College \\ Professor Dieter Sturma, Rheinische Friedrich-Wilhelms-Universität Bonn \\ Professor Allen Wood, Indiana University \\ Editorial Assistant: Alexandros Koutsoukis
}

Kantian Review is published in association with the UK Kant Society and the North American Kant Society. Special subscription rates are available to members of both societies. For details, please contact journals@cambridge.org.

SUBSCRIPTIONS Kantian Review (ISSN I 369-4 I 54 ) is published three times a year in March, July and November. Three parts form a volume. The subscription price (excluding VAT) of volume 2I (2OI6), which includes print and electronic access, is $£_{21} 4_{4}$ net (US\$333 in the USA, Canada and Mexico) for institutions; and $£_{54}$ net (Us $\$ 83$ in the USA, Canada and Mexico) for individuals, ordering direct from the publisher and certifying that the journal is for their personal use. Single parts are $£_{75}$ (US\$I I 6 in the USA, Canada and Mexico) plus postage. EU subscribers (outside the UK) who are not registered for VAT should add VAT at their country's rate. VAT-registered customers should provide their VAT registration number. Japanese prices for institutions (including ASP delivery) are available from Kinokuniya Company Ltd., P.o. Box 55, Chitose, Tokyo I 56, Japan. Prices include delivery by air where appropriate.

Orders, which must be accompanied by payment, may be sent to a bookseller, subscription agent or direct to the publisher: Cambridge University Press, Journals Fulfillment
Department, UPH, Shaftesbury Road, Cambridge CB2 8вS, UK; or in the USA, Canada and Mexico: Cambridge University Press, Journals Fulfillment Department, Ioo Brook Hill Drive, West Nyack, New York I0994-2I33, USA.

COPYING This journal is registered with the Copyright Clearance Center, 222 Rosewood Drive, Danvers, MA OI 923 , USA. Organisations in the USA who are registered with c.c.c. may therefore copy material (beyond the limits permitted by sections I07 and I08 of u.s. Copyright law) subject to payment to c.c.c. of the per copy fee of \$30. This consent does not extend to multiple copying for promotional or commercial purposes. Code I3694I 54/20I6. ISI Tear Sheet Service, 35 OI Market Street, Philadelphia, PA I9I04, USA, is authorised to supply single copies of separate articles for private use only. Organisations authorised by the Copyright Licensing Agency may also copy material subject to the usual conditions. For all other use, permission should be sought from Cambridge or from the North American Branch of Cambridge University Press.

This journal is included in the Cambridge Journals Online service which can be found at journals.cambridge.org.

(C) Kantian Review 2016 


\section{Contents}

\section{Articles}

I Kant on Proving Aristotle's Logic as Complete

Huaping Lu-Adler

27 On Kant's Duty to Speak the Truth

Thomas Mertens

53 Kant's Justification of Parental Duties

Heiko Puls

77 No King and No Torture: Kant on Suicide and Law Jennifer Uleman

IoI The Public Form of Law: Kant on the Second-Personal Constitution of Freedom

Ariel Zylberman

\section{Book Reviews}

I27 Flikschuh and Ypi (eds), Kant and Colonialism (Pascoe)

I30 Frierson, Kant's Empirical Psychology (Grenberg)

I3 8 Godlove, Kant and the Meaning of Religion: The Critical Philosophy and Modern Religious Thought (Mariña)

I4I Surprenant, Kant and the Cultivation of Virtue (Moran)

I46 Anderson, The Poverty of Conceptual Truth: Kant's Analyticl Synthetic Distinction and the Limits of Metaphysics (Goldberg)

I 5 I Ferrarin, The Powers of Pure Reason: Kant and the Idea of Cosmic Philosophy (Wilford)

\section{57 Books Received}

